\title{
STAPEDOTOMY TO TREAT MIXED HEARING LOSS IN OSTEOGENESIS IMPERFECTA: A CASE STUDY
}

\author{
Henryk Skarzynski ${ }^{1}$, Kamila Osinska ${ }^{1}$, Beata Dziendziel ${ }^{1}$, Piotr H. Skarzynski ${ }^{2,3}$ \\ ${ }^{1}$ Oto-Rhino-Laryngology Surgery Clinic, World Hearing Center, Institute of Physiology and Pathology of \\ Hearing, Warsaw/Kajetany \\ ${ }^{2}$ Heart Failure and Cardiac Rehabilitation Department, Medical University of Warsaw, Warsaw, Poland \\ ${ }^{3}$ Institute of Sensory Organs, Warsaw/Kajetany
}

Corresponding author: Kamila Osinska, Oto-Rhino-Laryngology Surgery Clinic, World Hearing Center, Institute of Physiology and Pathology of Hearing, Mochnackiego 10 Str., 02-042 Warsaw, Poland, e-mail: k.osinska@ifps.org.pl

\begin{abstract}
Background: Osteogenesis imperfecta is a congenital disorder underlain by an inherited deficiency of a connective tissue component. Different clinical symptoms related to various collagen mutations make it possible to distinguish several types of osteogenesis imperfecta. The most common four symptoms are defects of the osteoarticular system, sclera, skin, and hearing loss.

Case report: We report the case of a 60 year-old patient who was referred to the Institute of Physiology and Pathology of Hearing with bilateral progressive hearing loss, which she had first noted about 35 years ago. Based on clinical findings, the patient was diagnosed with osteogenesis imperfecta. She had a history of multiple bone fractures, short stature, and minor teeth malformations. No genetic test results were available for this patient. Based on results of an examination and the character of the hearing loss, the patient was referred for surgical treatment: explorative tympanotomy with bilateral reconstruction in stages. Both surgeries revealed fixation of the stapes and a thickened stapes footplate. Stapedotomies were performed in each ear. Follow-up after surgeries included pure tone audiometries.
\end{abstract}

Results: Surgical intervention resulted in closure or reduction of the air-bone gap on both sides, demonstrating effectiveness of the treatment.

Conclusions: In osteogenesis imperfecta hearing loss is a common comorbidity of anomalies in the osteoarticular system. A thickened and fixated stapes footplate can contribute to conductive component of hearing loss. Exploratory tympanotomy with stapedotomy is the method of choice in such cases. It allows the air-bone gap to be reduced and a subjective improvement of hearing, to reach, as this report demonstrates.

Key words: osteogenesis imperfecta $\bullet$ stapedotomy $\bullet$ mixed hearing loss

\section{TRATAMIENTO DE LA PÉRDIDA AUDITIVA EN LA OSTEOGÉNESSIS IMPERFECTA POR MEDIO DE LA ESTAPEDOTOMIA - DESCRIPCIÓN DEL CASO}

\section{Resumen}

Introducción: La osteogénessis imperfecta es una entidad patológica basada en un trastorno hereditario de la composición del tejido conectivo. Los síntomas clínicos variados relacionados con una amplia gama de la mutación del colágeno han dejado identificar algunos tipos de la osteogénessis imperfecta. En los 4 más frecuentes se notan principalmente defectos en la zona del sistema osteoarticular, de la esclerótica, de la piel y también una pérdida auditiva.

Métodos y material: La descripción de caso se refiere a una paciente de 60 años que se presentó en el Instituto de Fisiología y Patología del Oído con una pérdida auditiva bilateral. La paciente se dio cuenta de la pérdida auditiva hace 35 años. La paciente tiene diagnosticada una osteogénessis imperfecta. En el examen físico se diagnosticaron bilateralmente tímpanos conservados traslucidos. Se realizó una audiometría tonal, de la impedancia y un examen del umbral del reflejo del músculo estapedial bilateralmente. Como resultado de los exámenes realizados la paciente fue remitida a una operación. Después de la intervención quirúrgica se realizó un examen de control de la audiometría tonal.

Resultados: A resultas de las operaciones realizadas se consiguió un cierre de la reserva acústica de forma bilateral, lo cual sugiere una seguridad y eficacia del método de tratamiento aplicado.

Conclusiones: La pérdida auditiva en la osteogénessis imperfecta es un síntoma bastante frecuente relacionado con irregularidades en la zona del sistema osteo-artucular. La estructura del tejido óseo modificada a menudo causa un abultamiento y fijación de la plantilla. Esto se manifiesta como una pérdida auditiva conductiva o mixta que con el paso del tiempo puede 
empeorar. La timpanotomia exploratoria con estapedotomia es en este caso un tratamiento de elección, gracias al que se consigue la disminución de la reserva auditiva y una mejora auditiva subjetiva.

Palabras clave: osteogénessis imperfecta • estapedotomia • pérdida auditiva mixta

\section{ЛЕЧЕНИЕ ТУГОУХОСТИ ПРИ НЕСОВЕРШЕННОМ ОСТЕОГЕНЕЗЕ С ПОМОЩЬЮ СТАПЕДОТОМИИ - ОПИСАНИЕ СЛУЧАЯ}

\section{Изложение}

Введение: Несовершенный остеогенез - это заболевание, в основе которого лежит наследственное расстройство состава соединительной ткани. Различные клинические симптомы, связанные с широкой гаммой мутаций коллагена, позволили выделить несколько видов несовершенного остеогенеза. В самых поширенных четырех имеются, главным образом, дефекты в области костно - суставной системы, склеры, кожи, а также тугоухость.

Материал и методы: Описание случая касается 60-летней пациентки, которая обратилась в Институт Физиологии и Патологии Слуха по причине двусторонней тугоухости. Пациентка заметила появление тугоухости около 35 лет назад. У пациентки определен несовершенный остеогенез. В предметном исследовании обнаружено, что барабанные перепонки двусторонне сохранены, просвечивающие. Выполнена двусторонняя тональная импедансная аудиометрия и исследование порога импульса из стременной мышцы. В результате выполненных исследований пациентка была направлена на операционное лечение. После операций выполнены контрольные исследования тональной аудиометрии.

Результаты: В результате проведенных операций произошло двустороннее закрытие костно-воздушного интервала, это позволяет предполагать, что примененный метод лечения - безопасный и эффективный.

Итоги: Тугоухость при несовершенном остеогенезе - это довольно частый симптом, сопровождающий нарушения в области костно-суставной системы. Измененная структура костной ткани часто ведет к утолщениям и фиксации пластинки стремечка. Это проявляется в кондуктивной или смешанной тугоухости, которая со временем может углубляться. Эксплоративная тимпанотомия со стапедотомией в этом случае является предпочтительным видом лечения, благодаря которому можно получить уменьшение костно-воздушного интервала и субъективное улучшение слышания.

Ключевые слова: врожденная ломкость костей • стапедотомия • смешанная тугоухость

\section{LECZENIE NIEDOSŁUCHU W OSTEOGENESIS IMPERFECTA ZA POMOCĄ STAPEDOTOMII - OPIS PRZYPADKU}

\section{Streszczenie}

Wprowadzenie: Osteogenesis imperfecta jest jednostką chorobową, u której podstaw leży dziedziczne zaburzenie składu tkanki łącznej. Zróżnicowane objawy kliniczne związane z szeroką gamą mutacji kolagenu pozwoliły wyodrębnić kilka typów osteogenesis imperfecta. W 4 najczęściej występujących, notuje się głównie defekty w obrębie układu kostno-stawowego, twardówki, skóry a także niedosłuch.

Materiał i metody: Opis przypadku dotyczy 60-letniej pacjentki, która zgłosiła się do Instytutu Fizjologii i Patologii Słuchu z powodu obustronnego niedosłuchu. Pacjentka zauważyła niedosłuch około 35 lat temu. Pacjentka ma rozpoznaną osteogenesis imperfecta. W badaniu przedmiotowym stwierdzono obustronnie błony bębenkowe zachowane, przezierne. Wykonano audiometrię tonalną, impedancyjną oraz badanie progu odruchu z mięśnia strzemiączkowego obustronnie. W wyniku przeprowadzonych badań pacjentkę skierowano na leczenie operacyjne. Po zabiegach wykonano kontrolne badania audiometrii tonalnej.

Wyniki: W wyniku przeprowadzonych zabiegów operacyjnych uzyskano zamknięcie bądź zmniejszenie rezerwy ślimakowej obustronnie co sugeruje skuteczność zastosowanej metody leczenia.

Wnioski: Niedosłuch w osteogenesis imperfecta jest dość częstym objawem współtowarzyszącym nieprawidłowościom w obrębie układu kostno-stawowego. Zmieniona struktura tkanki kostnej skutkuje często pogrubieniem i fiksacją płytki strzemiączka. Objawia się to niedosłuchem przewodzeniowym bądź mieszanym, który z biegiem lat może pogłębiać się. Tympanotomia eksploratywna ze stapedotomią jest w tym przypadku leczeniem z wyboru, dzięki któremu uzyskuje się zmniejszenie rezerwy ślimakowej i subiektywną poprawę słyszenia.

Słowa kluczowe: wrodzona łamliwość kości • stapedotomia • niedosłuch mieszany 


\section{Background}

Osteogenesis imperfecta (OI) involves an increased susceptibility to bone fracture. It is a congenital connective tissue defect which can be present to different degrees in members of the same family, and not all individuals with the mutation develop the disease. It is estimated to affect 1 in 12,000-15 000 children [1]. First reports of this disease were as early as 1788 [2]. The first classification of the disease differentiated four types based on clinical symptoms and mode of inheritance [1]. In types I and IV, inheritance is autosomal dominant, while in types II and III recessive inheritance prevails. In 1983, a gene mutation responsible for OI was discovered: a deletion within the collagen-producing gene COLIA1 [3]. Subsequently, other mutations were identified in genes coding the collagen type I chains alpha 1 and alpha 2 (COLIA1 and COLIA2 respectively) [4]. Although the current classification includes 14 types of OI (which are distinguished based on the identification of new mutations [5]), however clinical symptoms and radiological findings are similar to those in the basic four types [6]. It is estimated that almost $90 \%$ of OI patients of European origin have the COLIA1/COLIA2 mutation [6].

Presently, the most popular OI classification scheme is that according to Sillence [7], which indicates the severity of a given type of OI. It classifies cases as one of five types. The mild types are Type 1 (no bone deformations, blue colour of sclera) and Type 4 (various degrees of deformations, normal sclera). Type 5 involves calcification of the interosseus membranes. The most severe types are Type 3 which is progressively deforming (most severe among living births with OI) and Type 2, which is perinatally lethal.

The most common clinical symptoms are bone fractures, so that only $10 \%$ of patients with OI Type 1 have no history of bone fracture in childhood [8]. Clinical symptoms are related to structures which accumulate collagen-rich connective tissue. A distinctive feature is bone deformation caused by

\section{A}

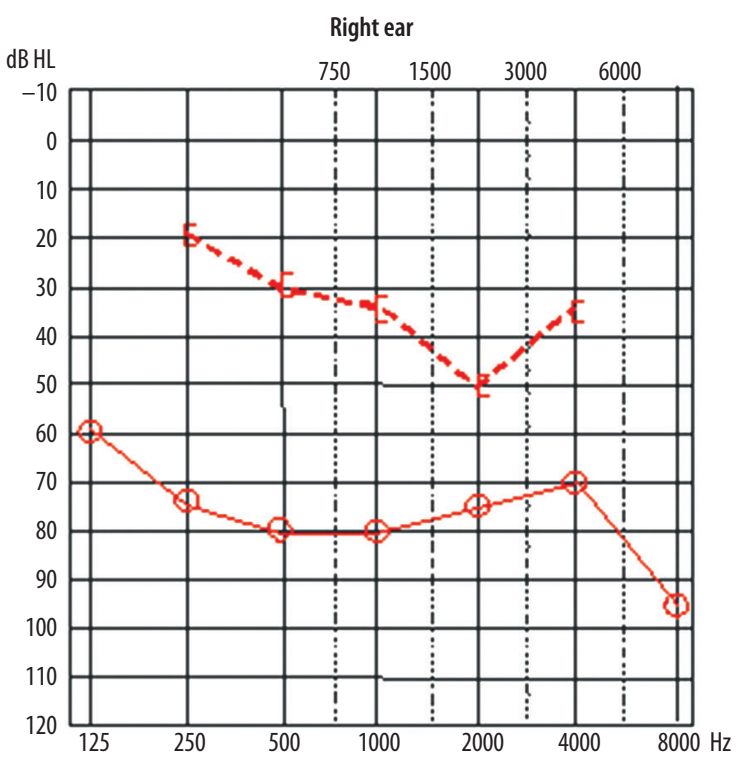

fracture and subsequent knitting, as well as a blue colour of the sclera caused by abnormal structure of connective tissue matrix. Small stature is another distinctive sign. Other symptoms include dysfunction of the aortic valve and dissection in the ascending part of the aorta, flaccid skin, difficult healing of wounds with formation of large scars, overly mobile joints, abnormal dental structure, and hearing loss, usually conductive, but also sensorineural or mixed [9].

In Type 1 cases, there is increased susceptibility to bone fracture, blue sclera, and hypoacusis which begins in adolescence or early adulthood. This symptom triad - fragile bones, blue sclera, and hearing loss - is described as Hoeve-de Kleyn syndrome and occurs in 1 in 25,000 live births [10]. Nearly $50 \%$ of patients diagnosed with Type 1 OI will develop a conductive or sensorineural hearing loss before they are 40 y.o. [11,12]. This pathology is often associated with vertigo [13].

In Types 3 and 4 , hearing loss is less frequent, occurring mostly in adults.

Hearing loss in OI can be progressive [8,14]. Usually the sensorineural component is noticed in patients after age 30 [14]. Some patients develop a profound sensorineural hearing loss, which can be remedied with a cochlear implant. Some reports of cochlear implantation in OI patients mention difficult intraoperative conditions [15].

The aim of the present work is to present a way of treating the conductive component of hearing loss in osteogenesis imperfecta. It sets out the clinical and intraoperative findings as well as demonstrating the hearing gain achieved after bilateral surgeries.

\section{Material and methods}

A 60-year old patient reported to a clinic with a progressive bilateral hearing loss, which had begun about 35 years

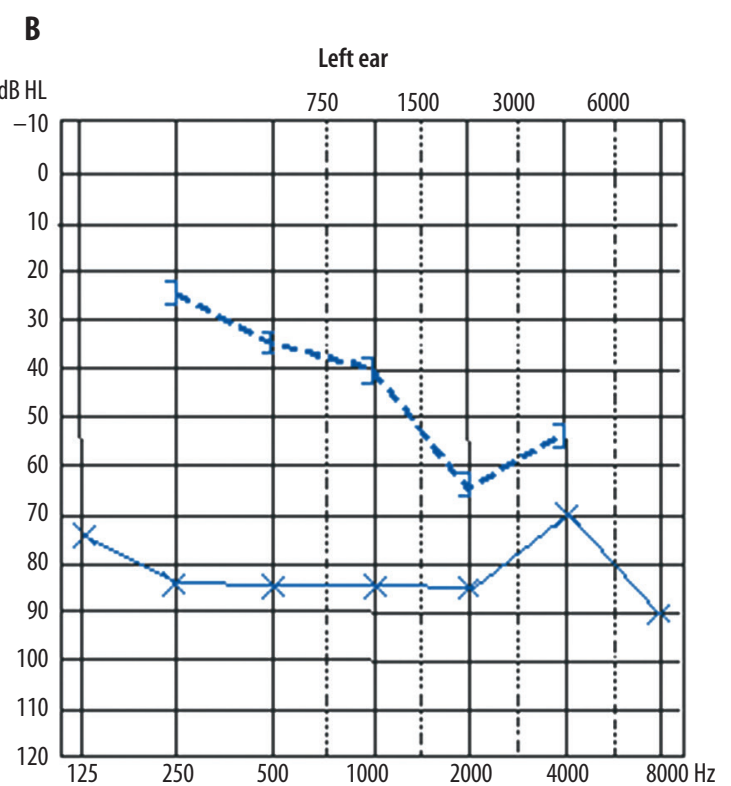

Figure 1. (A, B) Preoperative pure tone audiometry

(c) Journal of Hearing Science ${ }^{\circledR}$. 2015 Vol. 5 - No. 4 
A

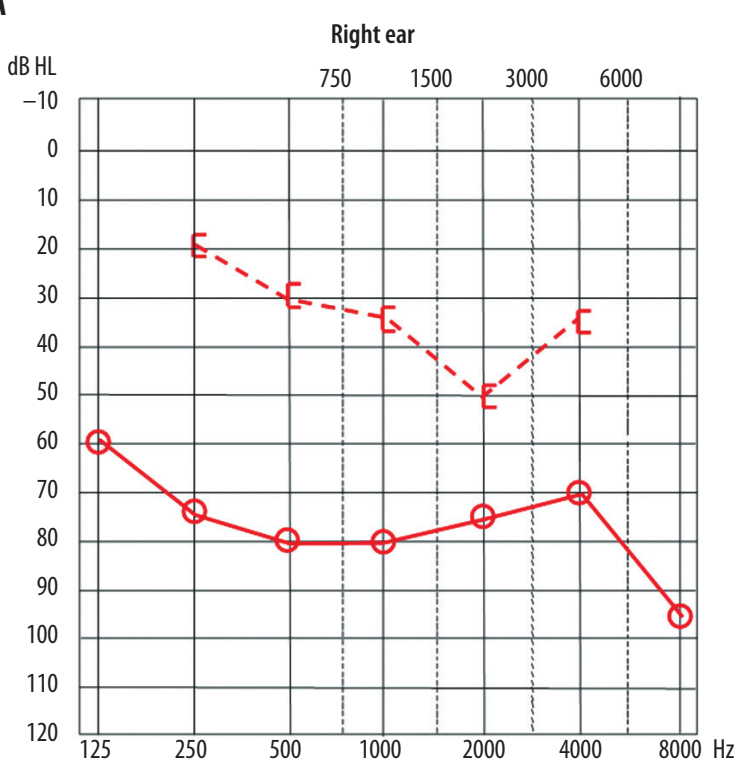

B

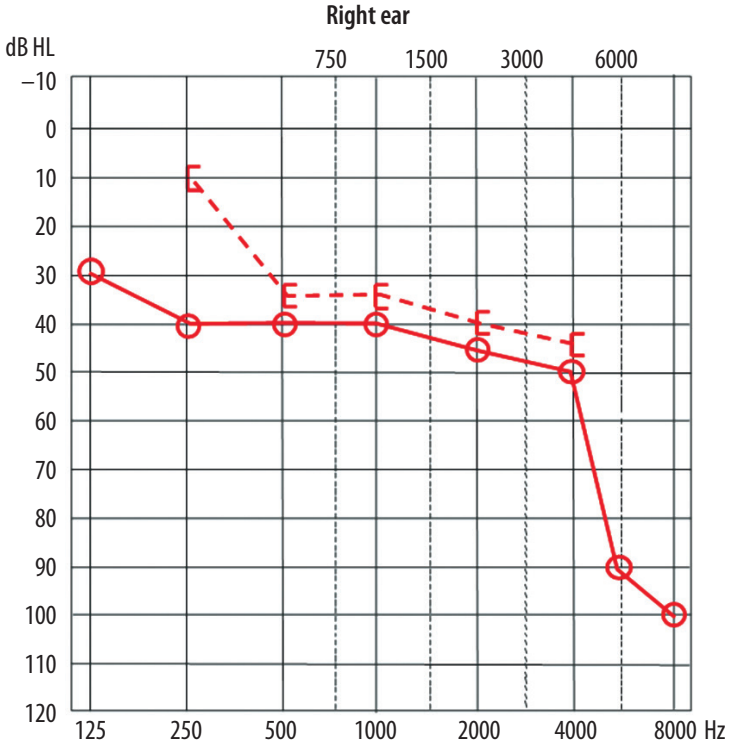

Figure 2. Pure tone audiometry on the right ear before surgery (A) and 2 months after surgery (B) showing closure of the air-bone gap

A

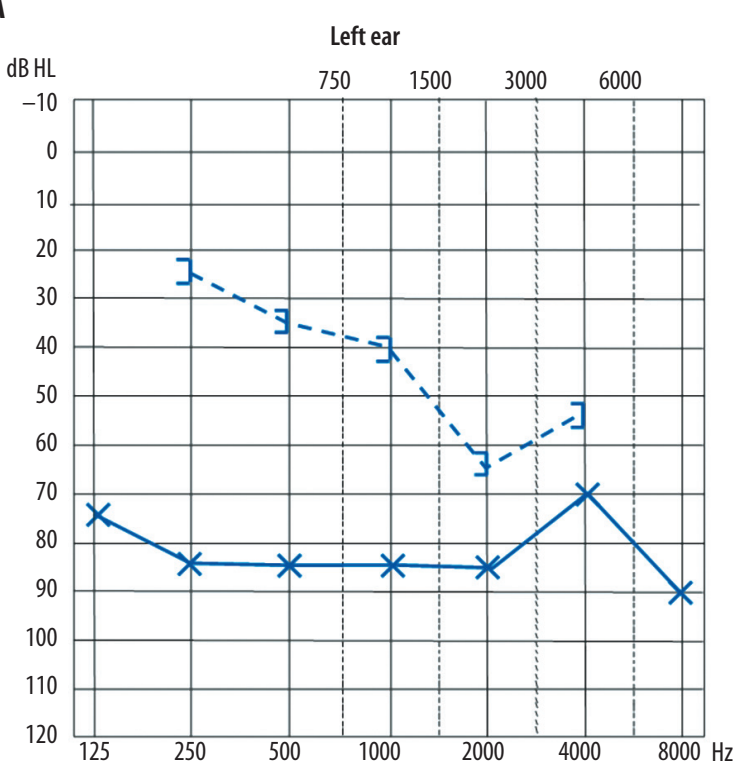

\section{B}

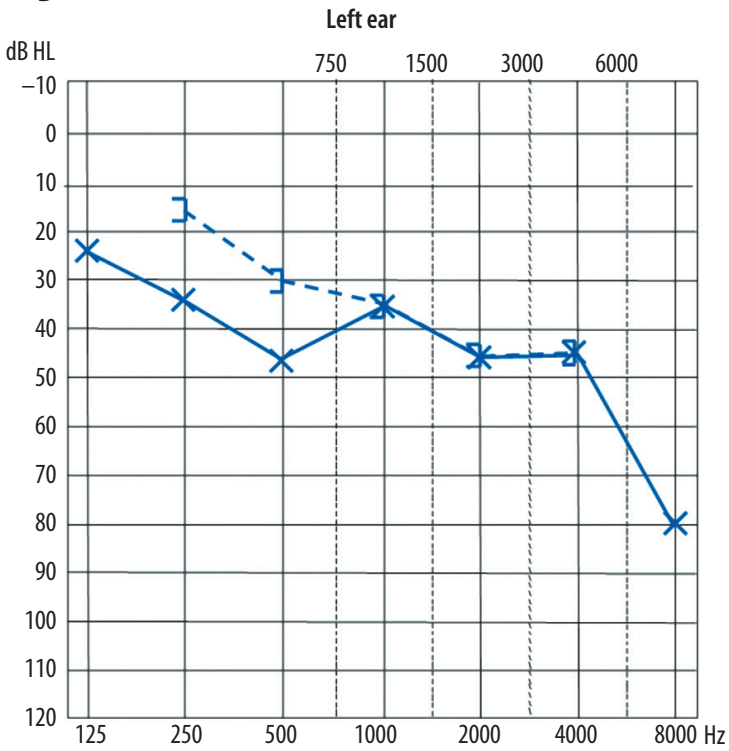

Figure 3. Pure tone audiometry on the left ear before surgery $(\mathbf{A})$ and one year later (B)

earlier. She had osteogenesis imperfecta. The diagnose of OI was made including the medical history of the patient. She underwent three orthopedic surgeries due to multiple bone fractures in childhood. Moreover she had high susceptibility to fractures, short stature, and some minor malformations of the teeth. No genetic tests had been done for this patient in the past. Her sclera was blue and there was no excessive joint mobility or flexibility of the skin. Additionally, the patient did have bilateral tinnitus and sporadic vertigo.

Under clinical examination her tympanic membranes were observed to be intact and opaque. Audiometric tests showed bilateral mixed hearing loss (Figure 1), a type A tympanogram, and lack of stapedius muscle reflex on both sides.

The decision was made to perform explorative tympanotomy on the right ear with eventual ossicular chain reconstruction. Intraoperatively, stapes fixation was observed. After removing the stapes suprastructure, a hole was drilled in the thickened and fixated stapes footplate near the promontory border. A prosthesis (Mikolow type III BO - a polytetrafluoroethylene piston connected with platinum tape) with diameter $0.6 \mathrm{~mm}$ was fixed and fastened 
A

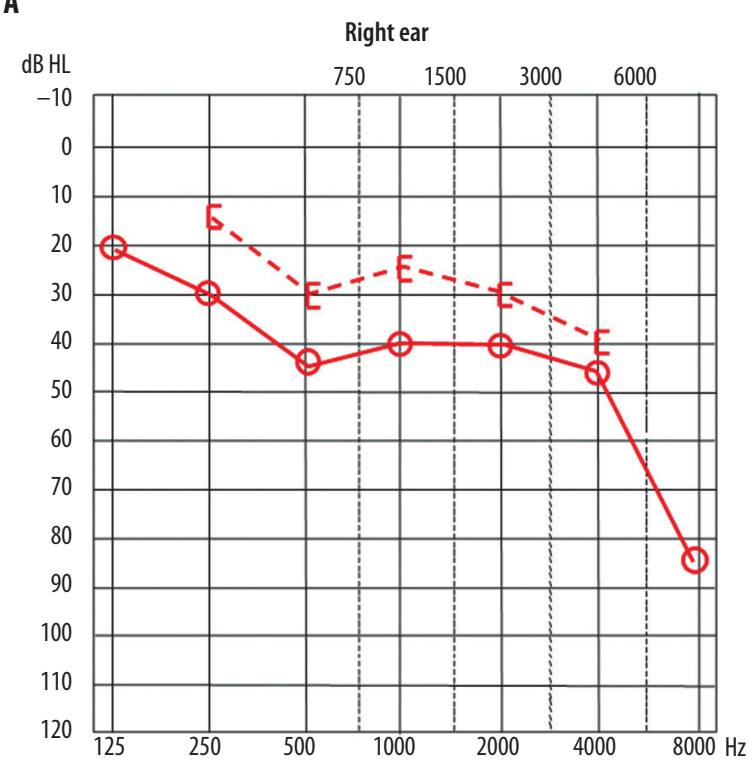

B

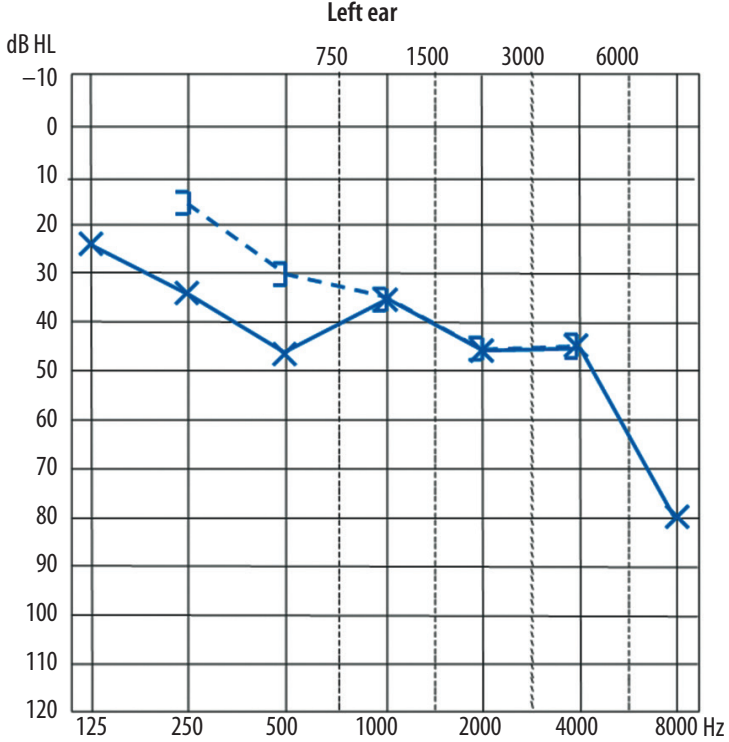

Figure 4. (A, B) Final measurements on both ears recorded one year after the left ear surgery and one year and 2 months after right ear surgery

to the long process of the incus. The bone channel was sealed with a clot of venous blood. A thickened mucosa of the middle ear and excessive bleeding were noted.

Follow-up pure tone audiometry was performed 2 months after surgery (Figure 2), and showed closure of the air-bone gap in the operated ear. Subsequently, surgery in the left ear was performed. Similar to the right ear, the stapes footplate was fixated and thickened. Again, a $0.6 \mathrm{~mm}$ Mikołów type III BO prosthesis was introduced into a hole in the footplate and fastened to the long process of the incus.

\section{Results}

Follow-up examinations were performed one year after each surgery. The results are shown in Figures 3 and 4 .

Note that the follow-up periods were different for each ear, since the second surgery was performed 2 months after the first. Figure 4 shows that significant hearing gain was achieved in each ear. After the second surgery the patient was not interested in any further short-term control.

\section{Discussion}

Diagnosis of osteogenesis imperfecta points to a risk of hearing loss. It is estimated that as many as $50 \%$ of patients with OI may develop hearing loss [14] of conductive, sensorineural, or mixed character. The sensorineural component is usually noticed after the third decade of life [14]. There are many publications on OI-related changes in ear structures. In accordance with the findings of $\mathrm{Ku}-$ urila et al. [11], who performed explorative tympanotomy in OI patients with hearing loss of a conductive kind, the usual intraoperative findings are a thickening of the stapes footplate, stapes fixation, or even obliteration. The stapes crura can be atrophied, overly flexible, or broken. In their paper summarizing histopathological analysis of the temporal bones of OI patients, Santos et al. [5] found that, in Type I cases, pathological lesions are usually located in the area of the oval window niche or round window niche, anomalies are related to the stapes (e.g. stapes crura not fixed to the footplate), and there is often obliteration of the scala tympani with a malformed organ of Corti and stria vascularis. Moreover, the membranous lining of the tympanic cavity is often thick and bleeds heavily during any middle ear procedure.

OI pathology is often related to difficult topical conditions during procedures on the middle or inner ear, and these may influence postoperative hearing results. The literature reports that stapes surgeries in Type I OI result in air-bone gap closure (air-bone gap of up to $10 \mathrm{~dB}$ ) in $75-85 \%$ of patients; this figure may be compared to an air-bone gap closure of $90-95 \%$ in stapes surgeries performed in other conditions [14]. Moreover, reports of cochlear implantation in OI patients with profound sensorineural hearing loss sometimes refer to advanced demineralization of the bony labyrinth. In some cases of OI, a correctly placed CI electrode array results in stimulation of the facial nerve [16].

Our case report shows findings typical for OI: thickened and fixated stapes footplates, thickened mucosa, and excessive bleeding during surgery [11]. After performed stapedotomies, long-term observations showed closure of the air-bone gap in the left ear and reduction in the right. This shows success of the method to treat conductive hearing loss, even under difficult surgical conditions. Despite the progressive character of hearing loss in OI $[8,14]$, we did not notice any deterioration of bone conduction thresholds in both ears.

\section{Conclusions}

The conductive component of hearing loss in osteogenesis imperfecta can be successfully treated using stapedotomy. 
It is important that the surgeon is aware of common anomalies in middle and inner ear structures found in patients with OI, since these can strongly affect intraoperative conditions. At the same time, a diagnosis of OI brings with it the risk of progressive hearing loss, so long-term followup is crucial in order to provide treatments appropriate to their medical history.

\section{References:}

1. Harrington J, Sochett E, Howard A. Update on the evaluation and treatment of osteogenesis imperfecta. Pediatr Clin North Am, 2014; 61(6): 1243-57.

2. Peltier LF. A brief historical note on the use of electricity in the treatment of fractures. Clin Orthop Relat Res, 1981; 161: $4-7$.

3. Chu ML, Williams CJ, Pepe G, Hirsch JL, Prockop DJ, Ramirez F. Internal deletion in a collagen gene in a perinatal lethal form of osteogenesis imperfecta. Nature, 1983; 304(5921): 78-80.

4. Marini J, Smith S. Osteogenesis imperfecta, Endotext [Internet].

5. Santos F, McCall A, Chien W, Merchant S. Otopathology in osteogenesis imperfecta. Otol Neurotol, 2012; 33(9): 1562-6.

6. Van Dijk F, Sillence D. Osteogenesis imperfecta: Clinical diagnosis, nomenclature and severity assessment. Am J Med Genet, 2014; 164A: 1470-1481.

7. Sillence D, Senn A, Danks D. Genetic heterogeneity in osteogenesis imperfecta. J Med Genet, 1979; 16: 101-16.

8. Sillence D. Bone dysplasia. Genetic and ultrastructural aspects with reference to osteogenesis imperfecta. Ann Arbor, Michigan: University Microfilms; 1980.

9. Forlino A, Cabral W, Barnes A, Marini J. New perspectives on osteogenesis imperfecta. Nat Rev Endocrinol, 2011; 7(9): $540-57$.
10. Steiner RD, Adsit J, Basel D. COL1A1/2-related osteogenesis imperfecta. Gene Reviews, 2013. [www.ncbi.nlm.nih.gov/books/ NBK1295/].

11. Kuurila K, Pynnönen S, Grénman R. Stapes surgery in osteogenesis imperfecta in Finland. Ann Otol Rhinol Laryngol, 2004; 113(3 Pt 1): 187-93.

12. Swinnen F, Dhooge I, Coucke P, Eufemia P, Zardo F, Garretsen $\mathrm{T}$ et al. Audiologic phenotype of osteogenesis imperfecta: Use in clinical differentiation. Otol Neurotol, 2012; 33(2): $115-22$.

13. Kuurila K, Kentala E, Karjalainen S, Pynnonen S, Kovero O, Kaitila I et al. Vestibular dysfunction in adult patients with osteogenesis imperfecta. Am J Med Genet, 2003; 120A: 350-8.

14. Vincent R, Wegner I, Stegeman I, Grolman W. Stapedotomy in osteogenesis imperfecta: A prospective study of 32 consecutive cases. Otol Neurotol, 2014; 35(10): 1785-9.

15. Vincent R, Gratacap B, Oates J, Sperling NM. Stapedotomy in osteogenesis imperfecta: A prospective study of 23 consecutive cases. Otol Neurotol, 2005; 26(5): 859-65.

16. Makizumi Y, Kashio A, Sakamoto T, Karino S, Kakigi A, Iwasaki $\mathrm{S}$ et al. Cochlear implantation in a patient with osteogenesis imperfecta. Auris Nasus Larynx, 2013; 40(5): 510-3 